\title{
Importance of potato late blight in Argentina, and the effect of fungicide treatments on yield increments over twenty years
}

\author{
Jorge D. Mantecón \\ Facultad de Ciencias Agrarias, Universidad Nacional de Mar del Plata, and Estación Experimental \\ Agropecuaria, Instituto Nacional de Tecnología Agropecuaria, INTA. Casilla 276, 7620 Balcarce, \\ Buenos Aires, Argentina.
}

\begin{abstract}
J.D. Mantecón. 2009. Importance of potato late blight in Argentina, and the effect of fungicide treatments on yield increments over twenty years. Cien. Inv. Agr. 36(1):115-122. Late blight (Phytophthora infestans) is the most destructive fungal disease of potato (Solanum tuberosum) in Argentina, reducing yields considerably. During the 1986-2005 growing seasons, fungicide treatments to control potato late blight were performed using mancozeb (Dithane M80 WP, Dow AgroScience Argentina, 1986-2005) every 7 d, metalaxil+mancozeb (Ridomil MZ 72 WP, Syngenta Agro Argentina, 1986-1995) every 14 d, and mefenoxam+mancozeb (Ridomil Gold 68 WP, 1996-2005) every 7 d. Blight severity was rated five times each season on the basis of the percentage of diseased foliage caused by late blight. Five visual assessments of infection were used to calculate the area under the disease-progress curve (AUDPC, foliar blight $\mathrm{x}$ day). Marketable ( $>60 \mathrm{~g}$ ) potatoes and total tuber yields were recorded each growing season. Late blight was prevalent and severe each year, reducing yields significantly particularly for marketable tubers. The average yields increased on fungicide treated plots was $41.8 \%$ for marketable tubers and $35.6 \%$ for total potato yields. Under the climatic conditions of southwest Argentina, total crop loss on non fungicide treated plots was not obtained in 20 years; therefore late blight was not a completely limiting factor for potato production. However, fungicide treatment appears to be essential to obtain high quality yields.
\end{abstract}

Key words: Chemical control, late blight, Phytophthora infestans, potato, potato diseases, Solanum, yield increases.

\section{Introduction}

Potato (Solanum tuberosum L.) is a main source of nourishment, comparable in importance to wheat and corn. It was the basic food of the pre-Columbian society. The first statistical data show that nearly 2,360 ha of potato was cultivated in Santa Fe province, Argentina in 1872, while towards the end of the 1930's, commer-

Received 04 March 2008. Accepted 13 October 2008. Corresponding author: jmantecon@balcarce.inta.gov.ar. cial potato exploitation in this region reached approximately 200,000 ha. This planting area was maintained for nearly three decades but the potato acreage tended to decline after 1970 with approximately 100,000 ha produced during the 1990's. This decrease in potato planting, however, did not affect total production, which increased up to nearly 2.0 to 2.5 million tons in the past years, with an average approximate yield of $29.5 \mathrm{t} \cdot \mathrm{ha}^{-1}$.

Late blight (Phytophthora infestans) is the most destructive fungal disease of potato worldwide, 
reducing the available photosynthetic area, which in turn reduces yields considerably (Cox and Large, 1960; Hooker, 1980). It is one of the few diseases that frequently cause a complete crop loss. Damages caused by late blight depend on the infection time and severity.

Clean potato seed, free of $P$. infestans, should be the primary control strategy because the pathogen can be transmitted by asymptomatic tubers used as potato seeds. Crop rotations, including non-susceptible crops, are also implemented to avoid volunteer potato plants. Potato fields should be far away from a pile of potatoes or other infected crop residues where the pathogen can survive.

Late blight was first found in Argentina in 1887, soon becoming the major foliar disease of potato (Carmona et al., 2003). Severe outbreaks have been reported since 1940. The disease causes different degrees of damage according to climate conditions during crop development. Fungicide treatment is the control strategy used to prevent the initial development of the disease. Fungicide spraying is commonly performed in a systematic manner over the entire crop cycle. In addition, potatoes grown for seed are commonly treated with herbicides prior to the end of the crop cycle as a means to reduce infection.

The most common potato cultivars used in Argentina are susceptible to late blight. Therefore, the systemic spraying of fungicides during the growing season is needed (Mantecón, 2005a). Fungicide frequency and dose depend on the type of fungicide, fungicide formulation, climatic conditions, and potato resistance levels (Mantecón, 2000a,b, and 1998a).

Disease prediction models for late blight are rarely used in Argentina; however, Wallin's prediction system (Wallin, 1962, 1951) has been validated there, enabling the timing of fungicide spraying against late blight. However, the results were satisfactory only when systemic fungicides were used (Mantecón, 2005b, 2006a, b). The protectant non-systemic fungicides used in Argentina are efficient in controlling late blight as they also control early blight (Alternaria solani). However, systemic phenylamide fungicides only control late blight, making them more specific, and sometimes more efficient for protection than non-systemic fungicides. Potato late blight control efficacy of Dithane M80 WP and Ridomil Gold $68 \mathrm{WP}$ and the yield increases due to fungicide treatment were similar in late blight trials during the growing seasons from 1996 to 2005 (Mantecón, 2007). In some production areas of Argentina, complementary irrigation is applied to all crops. This practice favors disease development in the crop.

The objectives of this work were to evaluate the importance of potato late blight in the southeast Buenos Aires province and to evaluate the control efficiency using systemic and non-systemic fungicides over an evaluation period of 20 years.

\section{Materials and methods}

\section{Potato crop}

Late blight $(P$. infestans) trials were carried out during a 20-year period (1986-2005). All field trials took place at the INTA Balcarce (Province of Buenos Aires, Argentina), and virus-free potato seeds cvs. Huinkul MAG (1986-1992) and Kennebec (1993-2005) were used. Both cultivars are susceptible to late blight. Field trials were fertilized and irrigated with an aspersion system as is customary done for commercial potato production in Argentina (Echeverría, 2006).

\section{Fungicides}

The evaluated fungicides were $2 \mathrm{~kg} \cdot \mathrm{ha}^{-1}$ mancozeb (Dithane M80 80\% WP, Dow AgroScience Argentina (1986-2005) sprayed every $7 \mathrm{~d} ; 2.5$ $\mathrm{kg} \cdot \mathrm{ha}^{-1}$ metalaxil+mancozeb $\left(200+1600 \mathrm{~g} \cdot \mathrm{ha}^{-1}\right)$ (Ridomil MZ 72\% WP, Syngenta Agro Argentina (1986-1995) sprayed every $14 \mathrm{~d}$; and 1.25 $\mathrm{kg} \cdot \mathrm{ha}^{-1}$ mefenoxan+mancozeb $\left(50+800 \mathrm{~g} \cdot \mathrm{ha}^{-1}\right)$ (Ridomil Gold 68\% WP, Syngenta Agro Argentina (1996-2005) sprayed every 7 d. Each year fungicide application started 47 days and ended 110 days after planting time, totaling 5 and 10 spray applications for treatments scheduled every $14 \mathrm{~d}$ and $7 \mathrm{~d}$, respectively. The 14 day schedule used for Ridomil MZ72 was reduced to a $7 \mathrm{~d}$ schedule for Ridomil Gold because disease con- 
trol efficacy increases when shorter spray application intervals are used (Mantecón, 2000a).

All fungicide treatments were applied with a backpack sprayer with constant pressure (2.75 bar) provided by a $\mathrm{CO}_{2}$ pressure source, equipped with ceramic disc-type cone nozzles $0.40 \mathrm{~m}$ apart at a rate of $290 \mathrm{~L} \cdot \mathrm{ha}^{-1}$.

\section{Evaluation}

Late blight severity was evaluated five times each growing season on the basis of the proportion of diseased foliage on a scale from 0 to 5 where $0=$ healthy, $1=$ first foliar symptoms present and no defoliation, $2=$ up to $25 \%$ defoliation plus foliar blight, $3=$ up to $50 \%$ defoliation plus foliar blight, $4=$ up to $75 \%$ defoliation plus foliar blight, and $5=100 \%$ defoliation. Evaluations began $60 \mathrm{~d}$ after planting time until the harvest. Data were expressed as the area under the disease-progress curve (AUDPC, foliar blight $\mathrm{x}$ day) (Jeger, and Viljanen-Rollinson, 2001). Marketable tuber ( $>60 \mathrm{~g}$ ) yields and total tuber yields were recorded each growing season using the two center rows of each plot.

\section{Design and statistical analysis}

Treatments were always distributed as a randomized complete block design with four replicates. The experimental units were plots of four rows, each with spacing of $4.0 \times 0.8 \mathrm{~m}$. Each experimental plot was spaced $2.0 \mathrm{~m}$ in all directions, and was bordered on all sides by unsprayed potato plants to promote disease development. Data were subjected to analysis of variance, and means were separated according to the LSD test $(p=0.05)$.

\section{Results and discussion}

Symptoms of late blight were characterized each year by partial to total foliage necrosis (Hooker, 1980). The first symptoms appeared on untreated foliage $71 \mathrm{~d}$ after planting, but the greatest severity was always observed between 104 and $110 \mathrm{~d}$ after planting (Figures 1 and 2).
Very high levels of AUDPC (>13332) were observed on untreated controls in the 1986, 1999, 2002 and 2003 growing seasons, which was possibly associated with the early manifestation of disease and the highly favorable environmental conditions registered those years. The lowest AUDPC levels were observed in the 1996 and 1998 seasons with an AUDPC of 1415 and 1208, respectively. Every season, a significantly lower AUDPC $(p=0.05)$ was detected on fungicidetreated plots than on untreated check plots, confirming the fungicide efficacy that had been previously reported for these fungicides (Figure 2) (Mantecón, 1998a,b, and 2000a, b).-

Potato late blight is favored by high moisture and moderate temperatures for periods of several hours (Cox, and Large, 1960; Fry, et al., 1992; Wallin, 1962). Night temperatures of $10-15^{\circ} \mathrm{C}$, day temperatures of $15-22^{\circ} \mathrm{C}$, rain, sprinkler irrigation, and high relative humidity $(>90 \%)$ are considered to be the most favorable conditions for disease development. In the southeast Buenos Aires province, the environmental conditions for the development of late blight disease were favorable each year of evaluation, leading to a severe late blight infection with the maximum disease severity affecting untreated controls (5 in a 0 to 5 scale).

The fungicide was highly effective, reducing foliar infection significantly. Only in 1993 was a significant difference $(\mathrm{p}=0.05)$ in the performance of Dithane M80 and Ridomil MZ observed, with Ridmil MZ providing the best disease control. Similarly, no significant differences $(p=0.05)$ were obtained between Dithane M80 and Ridomil Gold. These results suggest that differences between contact and systemic fungicides were slight or non-existent for controlling $P$. infestans on potatoes in southwest Argentina (Mantecón, 2000b). However, when climatic conditions were very favorable to disease development, systemic fungicides were better than contact fungicides for foliar blight control when spayed at the same spray interval schedule (Mantecón, 2000a).

Considering that the metalaxyl and mefenoxam fungicides are highly specific in their mode of action, and may induce resistance in a rather short period, it was interesting to demonstrate 

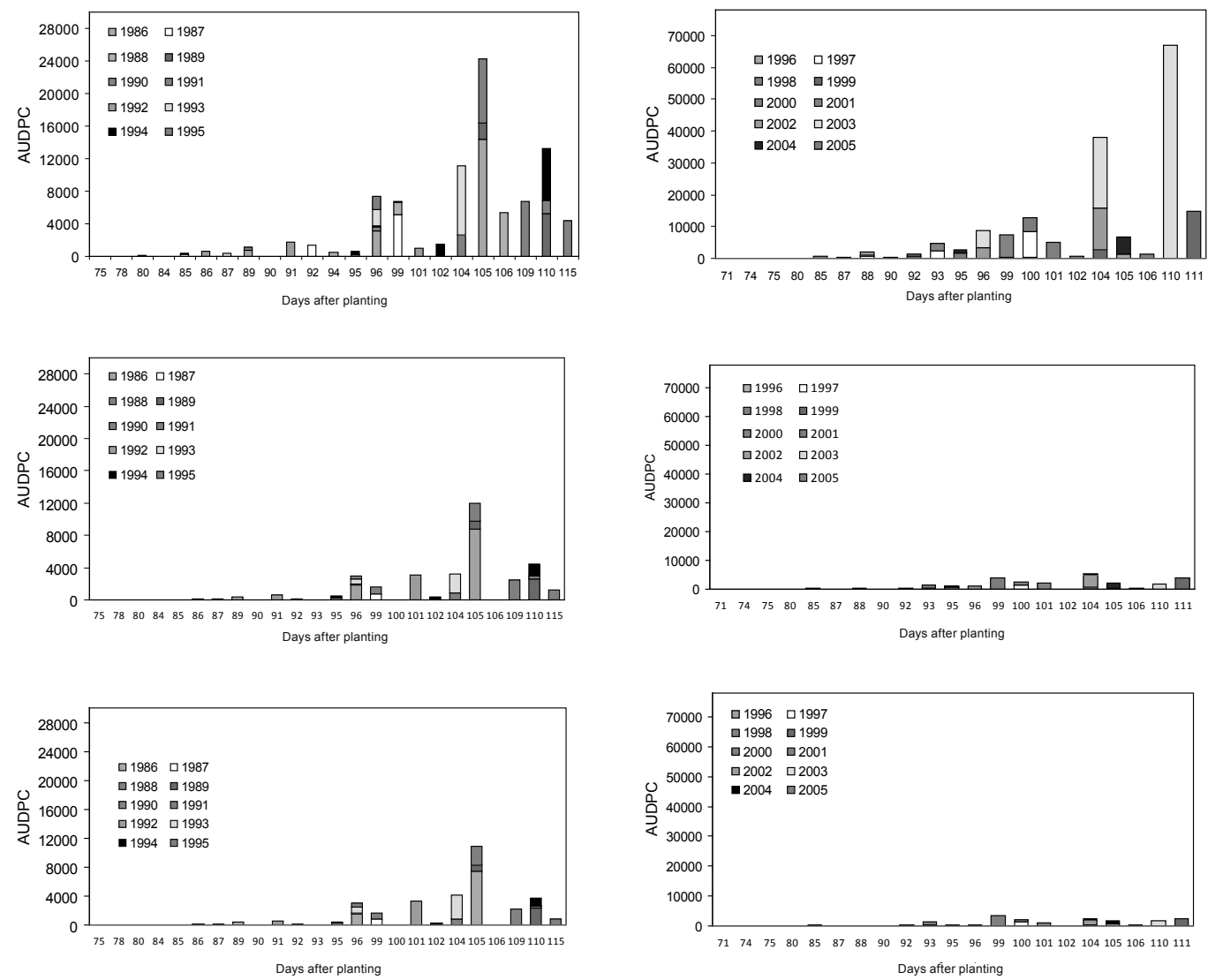

Figure 1. Effect of fungicide treatments on the foliar development of late blight (Phytophthora infestans) on potato (Solanum tuberosum), determined each year by the area under the disease-progress curve (AUDPC, foliar blight $\mathrm{x}$ day). Potato cultivars were Huinkul MAG and Kennebec (in the 1986-1992 and 1993-2005 periods, respectively) and both are susceptible to late blight. Treatments were untreated controls (A and B), $2 \mathrm{~kg} \cdot \mathrm{ha}^{-1}$ mancozeb (Dithane M80 80\% WP) sprayed every $7 \mathrm{~d}\left(\mathrm{C}\right.$ and D); $2.5 \mathrm{~kg} \cdot \mathrm{ha}^{-1}$ metalaxil+mancozeb $\left(200+1600 \mathrm{~g}^{-h^{-1}}\right.$ ) (Ridomil MZ 72\% WP), sprayed every 14 $\mathrm{d}(\mathrm{E})$; and $1.25 \mathrm{~kg} \cdot \mathrm{ha}^{-1}$ mefenoxan+mancozeb $\left(50+800 \mathrm{~g} \cdot \mathrm{ha}^{-1}\right)$ (Ridomil Gold 68\% WP) sprayed every $7 \mathrm{~d}(\mathrm{~F})$.

that $2 \mathrm{~kg} \mathrm{ha}^{-1}$ mancozeb, a low resistance risk fungicide which can be apply as a protectant fungicide on a $7 \mathrm{~d}$ schedule, providing excellent control. Resistance risks against mancozeb are very low but different $P$. infestans strains may also have different sensitivities (Kato et. al. 1997; Brent and Hollomon, 2007).

Yields significantly increased $(\mathrm{p}<0.05)$ on treated plots as compared with untreated controls (Figure 2). Yield differences obtained between treated and untreated controls were higher in marketable tubers than in total yields. The average yield increase over an evaluation period of 20 years was $41.8 \%$ for marketable tuber yields and $35.6 \%$ for total yields. During the 1986-1995 growing period, yield increases on fungicide-treated plots of $37.3 \%$ and $42.3 \%$ were obtained for total yield and marketable tubers, respectively. Similarly, potato yield increments of $41.2 \%$ for marketable tubers, and $33.9 \%$ for total yields were obtained during the 1996-2005 growing period. The overall average yield of marketable tubers increased by 40.5 and $41.8 \%$ on plots treated with Dithane M80 and Ridomil MZ (or Ridomil Gold). Under the climatic conditions of Argentina, late blight partially limits potato production, and even with very favorable environmental conditions a total yield loss in the untreated controls were not obtained in 20 years of evaluations. Therefore, potato late blight causes a higher damage 

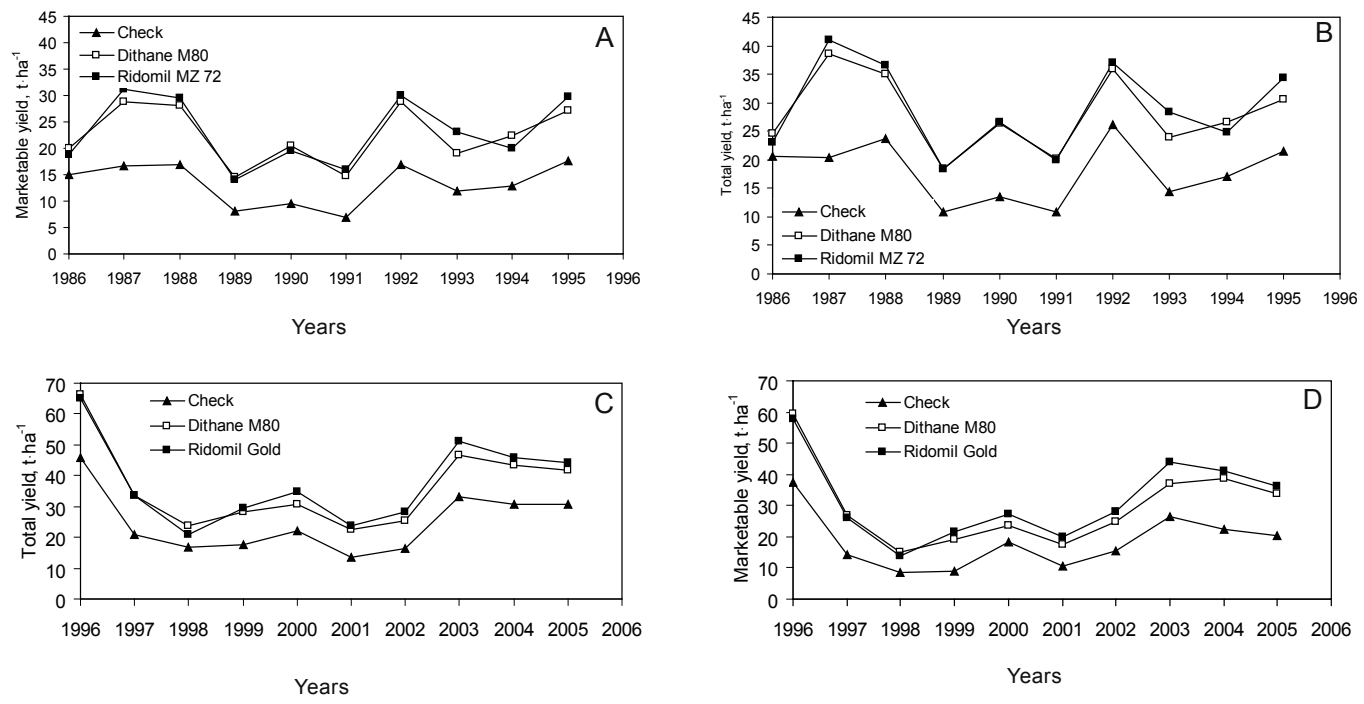

Figure 2. Effect of late blight (Phytophthora infestans) and fungicide on the marketable and total yields of potato (Solanum tuberosum), in the growing seasons from 1986 to 1995 (A and B) and from the 1996 to 2005 growing seasons (C and D). Potato cultivars were Huinkul MAG and Kennebec in the 1986-1992 and 1993-2005 periods, respectively, and both are susceptible to late blight. Fungicides were $2 \mathrm{~kg} \cdot \mathrm{ha}^{-1}$ mancozeb (Dithane M80 80\% WP) sprayed every $7 \mathrm{~d} ; 2.5 \mathrm{~kg} \cdot \mathrm{ha}^{-1}$ metalaxil+mancozeb $\left(200+1600 \mathrm{~g} \cdot \mathrm{ha}^{-1}\right)\left(\right.$ Ridomil MZ 72\% WP), sprayed every $14 \mathrm{~d}$; and $1.25 \mathrm{~kg} \cdot \mathrm{ha}^{-1}$ mefenoxan+mancozeb $\left(50+800 \mathrm{~g} \cdot \mathrm{ha}^{-1}\right)($ Ridomil Gold $68 \% \mathrm{WP})$ sprayed every $7 \mathrm{~d}$.

to marketable tubers, reducing tuber size, than on the total number of tubers.

Potato late blight has been quite prevalent and severe under the climate conditions of south- east Argentina, reducing yields significantly. Contact or systemic fungicide sprays reduce the severity of foliar blight and significantly increase the number of marketable tubers and the total yield.

\section{Resumen}

J.D. Mantecón. 2009. Importancia del tizón tardío de la papa en Argentina y efecto de tratamientos fungicidas sobre los rendimientos en veinte años. Cien. Inv. Agr. 36(1):115122. El tizón tardío (Phytophthora infestans) de la papa (Solanum tuberosum) es la enfermedad más importante de este cultivo en Argentina, que provoca considerables pérdidas de rendimiento. Durante 20 años (1986-2005) se evaluó la importancia del tizón tardío de la papa y la eficacia de tratamientos fungicidas de contacto y sistémicos para su control, en condiciones climáticas del sur oeste de Argentina. Los fungicidas utilizados fueron mancozeb (Dithane M80 WP, Dow AgroScience Argentina, 1986-2005) cada 7 d, metalaxil+mancozeb (Ridomil MZ 72 WP , Syngenta Agro Argentina, 1986-1995) cada 14 d y mefenoxan+mancozeb (Ridomil Gold 68 WP, Syngenta Agro Argentina, 1996-2005) cada 7 d. La severidad de la enfermedad se evalúo en cinco oportunidades durante cada año y ciclo de cultivo usando una escala 0 a 5 según porcentaje de infección foliar. Estos valores se utilizaron para calcular los valores el área bajo la curva de progreso de la enfermedad (AUDPC, tizón foliar x días). Se analizó el rendimiento de tubérculos comerciales $(>60 \mathrm{~g})$ y total. La enfermedad prevaleció en forma severa cada año. Los rendimientos alcanzados en parcelas tratadas fueron siempre significativamente superiores a los 
testigos sin tratar. El promedio de incremento debido a la pulverización de fungicidas fue $41,8 \%$ en tubérculos comerciales y $35,6 \%$ en rendimiento total. La pérdidas de rendimientos fueron mayores en tubérculos comerciales que en el número total de tubérculos. Bajo condiciones climáticas de Argentina, el tizón tardío no es totalmente limitante del cultivo dado que, durante 20 años, no se verificó pérdida total del rendimiento en las parcelas testigo sin tratamiento fungicida. No obstante, el uso de fungicida probó ser esencial para obtener altos rendimientos de papa con calidad comercial.

Palabras clave: Control químico, enfermedades de la papa, papa, Phytophthora infestans, rendimientos, Solanum, tizón tardío.

\section{References}

Brent, K.J., and D.W. Hollomon. 2007. Fungicide resistance in crop pathogens: How can it be managed? FRAC Monograph 1, second edition, Fungicide Resistant Action Committee, 56 pp.

Carmona, D., M. Huarte, G. Arias, A. López, A.M. Vincini, H.A. Alvarez Castillo, P. Manetti, E. Chávez, M. Torres, J. Eyherabide, J. Mantecón, L. Cichón, and D. Fernández. 2003. Integrated Pest Management in Argentina. Pages 313-326. In: K.M. Maredia (ed.). Integrated Pest Management in the Global Arena. Institute of International Agriculture and Department of Entomology, Michigan State University. East Lansing, MI, USA.

Cox, A.E., and E.C. Large. 1960. Potato blight epidemics throughout the world. ARS/USDA Handbook No. 174. Washington, DC, USA. 230 p.

Echeverría, H.E. 2006. Fertilización del cultivo de papa. Estación Experimental Agropecuaria INTA Balcarce. PROPAPA. Actualidad Papera 5:6-7.

Fry, W.E., S.B. Goodwin, M.J. Matuszak, L.J. Spielman, and M.G. Milgroom. 1992. Population genetics and intercontinental migrations of Phytophthora infestans. Ann. Rev. Phytopathol. 30:107-130.

Hooker, W.J. 1980: Compendio de Enfermedades de la Papa: 56-60 pp. The American Phytopathological Society. St. Paul, Minnesota, MN, USA. $166 \mathrm{pp}$.

Jeger, M.J., and S.L.H.Viljanen-Rollinson. 2001. The use of the area under the disease-progress curve (AUDPC) to assess quantitative disease resistance in crop cultivars. TAG Theoretical and Applied Genetics 102:32-40.

Kato, M., E.S. Mizubuti, S.B. Goodwin, and W.E. Fry. 1997: Sensitivity to Protectant Fungicides and Pathogenic Fitness of Clonal Lineages of Phytophthora infestans in the United States. Phytopathology 87:973-978.

Mantecón, J.D. 1998a. Minimum dose of mancozeb that offer effective control of potato late blight in Argentinean conditions. Fungicide and Nematicide Test 53:200-201.

Mantecón, J.D. 1998b. Potential yield losses caused by late blight in Argentina during the last decade. Fungicide and Nematicide Test 53:202-204.

Mantecón, J.D. 2000a. Influence of acylalanine fungicide application interval on potato late blight control. Fungicide and Nematicide Test 55:221.

Mantecón, J.D. 2000b. Management of potato late blight with several mancozeb formulations. Fungicide and Nematicide Test 55:217-218.

Mantecón, J.D. 2005a. Potato late blight control by fungicide applications, 2003. Fungicide and Nematicide Test 60:142.

Mantecón, J.D. 2005b. Potato late blight control using a disease prediction model under Argentina conditions, 2001-2002. Fungicide and Nematicide Test $60: 140$.

Mantecón, J.D. 2005b. Effect of dose, surfactants and spray interval on fungicidal control of potato late blight, 2002. Fungicide and Nematicide Test 60:141.

Mantecón, J.D. 2006a. Potato late blight control with systemic fungicide using a disease prediction model in Argentina conditions, 2004. Fungicide and Nematicide Test 61:144.

Mantecón, J.D. 2006b. Potato late blight control with systemic fungicide using a disease prediction model in Argentina conditions, 2005. Fungicide and Nematicide Test 61:145.

Mantecón, J.D. 2007. Potato yield increases due to fungicide treatment in Argentinian early blight (Alternaria solani) and late blight (Phytophthora infestans). Field Trials During the 
1996-2005 Seasons. Online. Plant Management Network. Plant Health Progress, February 2007. doi:10.1094/PHP-2007-0202-01-RS.

Wallin, J.R. 1951. Forecasting tomato and potato late blight in the northcentral region. Phytopathology 41:37.(Abstract) .
Wallin, J.R. 1962. Summary of recent progress in predicting the late blight epidemics in United States and Canada. American Potato Journal 39:306-312. 
